\title{
Awareness on presentation of obstetric fistula and associated factors among reproductive age women in south eastern zone of tigray,ethiopia,2020.cross sectional study
}

Berhane Teklay Asfaha ( $\nabla$ wedimereb2010@gmail.com )

Assosa University https://orcid.org/0000-0002-0782-7786

Haftu Berhe Gebru

Mekelle University College of Health Sciences

Desta Siyoum Belay

Mekelle University College of Health Sciences

Teferi Gebru Gebremeskel

Aksum University

Research

Keywords: Obstetric Fistula, Presentation, Awareness, Reproductive age women

Posted Date: October 19th, 2021

DOl: https://doi.org/10.21203/rs.3.rs-966802/v1

License: (c) (1) This work is licensed under a Creative Commons Attribution 4.0 International License.

Read Full License 


\section{Abstract \\ Background}

Worldwide, around one million girls and women are currently living with fistula. Less than 20,000 women with obstetric fistula are treated each year. Lack of awareness is a frequently mentioned barrier to seeking fistula treatment; many women suffering from obstetric fistula do not know what fistula is, as it is treatable, or where to get treatment. Even though obstetric fistula has likely weighed down women since the beginning of time, few researches proportionally exists.

\section{Methods}

A community based quantitative cross-sectional survey was undertaken in south eastern zone of Tigray. A multistage random sampling technique was implemented to select total participants of 605 reproductive age women. Two districts were randomly selected and from those districts, 12 kebels were selected randomly and the calculated sample size (605) was proportionally allocated to each selected kebeles. The data were collected by using face to face/interview with structured questionnaire from February 26-March 24/2020 after ensuring that all requirements of ethical considerations were fulfilled. The collected data were entered in to Epidata version 4.2 then exported to SPSS version20 for analysis. Descriptive statistics with frequency, percentage, table and graph and cross tabulation were used for presentation of result. Bivariable and multivariable analysis were used to examine the association. Odds ratios with $95 \%$ confidence interval and P-value $<0.05$ were used to determine the statistical association.

\section{Result}

Overall, about $31.6 \%$ of respondents had good awareness on presentation of obstetric fistula. The major determinant factors identified to awareness on presentation of obstetric fistula were educational level (above secondary) $[\mathrm{AOR}(95 \% \mathrm{Cl}=2.9(1.42-9.6)]$, history of institutional delivery (for the index child)[AOR $(95 \% \mathrm{Cl}=4.1(1.76-9.56)]$ and having prior information about obstetric fistula[AOR $(95 \% \mathrm{Cl}=2.2(1.01-4.75)]$.

\section{Conclusion}

In this study majority of reproductive age women in the study area had poor awareness regarding presentation of obstetric fistula. Several interventions like health education and information should be implemented to enhance the awareness of the community towards obstetric fistula.

\section{Plain English Summary}

Obstetric fistula is an abnormal opening between a woman's genital tract and her urinary tract and rectum. The development of obstetric fistula is directly linked to obstructed labour which is one of the 
major causes of maternal mortality. Each year between 50000 to 100000 women worldwide are affected by obstetric fistula. 605 respondents were asked about presentation of obstetric fistula and around $31.6 \%$ of them had good awareness regarding presentation on obstetric fistula. The major determinant factors identified to awareness on presentation of obstetric fistula were, level of education (above secondary), having history having prior information about obstetric fistula, institutional delivery (for the index child).

In Conclusion; majority of reproductive age women in the study area had poor awareness regarding presentation of obstetric fistula. Several interventions like health education and information should be implemented to enhance the awareness of the community towards risk factors for obstetric fistula.

\section{Introduction}

Obstetric fistula is abnormal passage way between the vagina and bladder or rectum may develop after prolonged and obstructed labor and lead to continuous urinary or fecal incontinence(1). Obstetric fistula can happen between the bladder and the vagina, between the rectum and vagina or both, leading to uncontrolled leakage of urine and/or feces(2).

The commonest type of obstetric fistula is Vesico-vaginal Fistula (VVF) which accounts $79 \%$ of cases but there are also cases of Recto Vaginal Fistula (RVF) 1-8\% and combined (VVF and RVF) 1-23\%.Obstetrics fistula is related with numerous risk factors, and they appear to be escapable. This condition is related with young status at delivery, primi-parity, prolonged labor and home delivery(3).

In developed countries surgery and radiotherapy are the major risk factors for the situation, while obstetric complications are the main risk factors in developing nations, fistulas are also found in other parts of the world where fertility is high, the economic status of women is low, and obstetric services are poor, such as in Afghanistan, Pakistan, Bangladesh and parts of India (4).

Globally, around one million girls and women are currently suffering from obstetric fistula, Less than 20,000 women with obstetric fistula are treated each year. Obstetric fistula is a disease of poverty(5).Obstetric fistula occurs in all developing countries especially in the Northern half of SubSaharan Africa from Mauritania to Eritrea and in the developing countries of the Middle East and Asia(6).

Obstetric fistula prevention strategies classifies into primary prevention strategies (focused on contraception), secondary prevention strategies (ensuring women can access skilled care for delivery) and tertiary prevention strategies (early screening for fistula for most at risk women. Fistula is treatable as well as preventable. The success rates of obstetric fistula surgery in the literatures are between 70 to 90 per cent for simple fistulas, and between 30 and 60 per cent for complex or complicated cases. The world is standing by declaring May 23 as the International Day to end obstetric fistula and the decision to continue to use this Day each year to extensively raise knowledge and strengthen actions towards ending obstetric fistula(7). 
Resolution adopted by the General Assembly on 25 September, 2015 (Sustainable Development Goal) states under Target 3.7: by 2030, ensure universal access to sexual and reproductive health-care services, including for family planning, information and education, and the integration of reproductive health into national strategies and programs(8).

Obstetric fistula is a source of concern to medical practitioners in developing countries, awareness about it and the risk factors appear inadequate. There is need to appropriately inform women during their antenatal clinic visits about the risk factors for obstetric fistula and where to find care when faced with this challenge(9).

Obstetric fistula is considered to be the most worrying morbidity that affects women following childbirth. Medical consequences of fistula include incontinence, infection and possibly infertility. Social consequences of fistula are isolation, abandonment, disgrace and vulnerability(10).

Awareness is the ability to directly know and perceive, to feel, or to be heedful of events, More broadly, it is the state of being conscious of something(11).

Lack of awareness is a frequently mentioned barrier to seeking fistula treatment; many women who suffer from obstetric fistula do not know what fistula is, that their condition is treatable, or where to get treatment. Women with fistula and members of their community may also be misinformed about the causes of fistula, in some communities fistula is believed to be a curse or a punishment from God(12).

Occurrence of obstetric fistula is highly related with lack of awareness (misperception) on risk factors of obstetric fistula. Majority of respondents associated obstetric fistula directly with mistakes made by hospital personnel or problems during procedures other than other risk factors and this perception reduces health seeking behavior(13).

Many of women are not aware of how to prevent obstetric fistula. If such women develop obstetric fistula during the process of childbirth it is also difficult for them to get treatment since they may not even be aware that it can be treated(10) .

Deficiency of knowledge on presentation of obstetric fistula hinders seeking treatment(14).

Even though obstetric fistula has likely weighed down women since the beginning of time, very little research proportionally exists. For obstetric fistula, there is a desperate need for rigorous and ethical research(15).

\section{Methods}

Study setting

Tigray regional state is one of the nine regional states of Ethiopia, which found in the northern part of Ethiopia. The capital city of Tigray is mekelle city which is $781 \mathrm{~km}$ far from Addis Ababa. 
South eastern zone is one of the zones in the Ethiopian region of Tigray. It bordered on the south by southern zone, on the south east by Amhara region, on the north east by central zone, on the north by eastern zone and on the east by the Afar region. As the zone was created after the census of 2007, it is hard to find correct data about the population of zone. The estimated size of population according to 2007 census conducted by the CSA was 392,142 , of which 21,125 or $5.39 \%$ where urban dwellers(16). South eastern zone contains four districts known as Endrta, HintaloWejerat, Samre and DeguaTemben and a total of 87 kebeles.In each woredas Endrta has 17 kebeles, Hintalo wejerat 23.Samre 23, and DeguaTemben has 25 kebeles and it has three primary hospitals, 24 health centers and around 73 health posts.

The study was conducted from February 26-Murch 24/2020 in south eastern zone of Tigray.

\section{Participants}

Sampled Reproductive age women living in south eastern zone of Tigray and who fulfill the inclusion criteria were taken as the study population. All reproductive age group women who were mentally stable, those availabled at the time of data collection period, women who were not severely ill were included, While Reproductive age women who are health professionals or working on health and health related fields were excluded.

Sample size determination and sampling technique

The sample size was calculated using a single population proportion formula with the following assumption: Prevalence of awareness on risk factor for obstetric fistula was $50 \%, 95 \%$ of confidence interval(1.96), $5 \%$ margin of sampling error tolerated, $5 \%$ of non-response rate, 1.5 design effect ,then the final sample size was 605. Multistage random sampling technique was used to select the total of 605 study participants.

In south eastern zone of Tigray there are four districts namely Endrta, DeguaTemben, saharti samre and HintaloWejerat.

For this study two districts were selected using simple random method. Within each selected districts there are 87 kebeles so it is difficult to include all of them rather $30 \%$ of the total kebeles were selected randomly.

Within each kebele there were list of households which has reproductive age group women. This list was used as sampling frame to use simple random sampling. Then the calculated sample size (605) was proportionally allocated to each selected kebeles.

In the case of two or more reproductive age women in the same household, one mother was selected using the lottery method.

Study Variables

\section{Dependent Variable}

Dependent Variable:

Awareness on presentation of obstetric fistula

\section{Independent Variables}


Socio-Demographic factors (Age, marital status Religion, women education, occupation, age of marriage and residence).

Obstetric factors (history of contraceptive use, history of induced abortion history of pregnancy, history of ANC, site of previous delivery).

Other factors (presence of health center, history of birth related complication, awareness on risk of complication, media exposure).

Definition of terms

\section{Awareness}

Is a characteristics, outlook or understanding of an individual towards obstetric fistula presentation.

\section{Good Awareness on presentation of obstetric fistula}

Participants who scored mean score or above were assigned as they have good awareness on presentation of obstetric fistula.

\section{Poor Awareness on presentation of obstetric fistula}

Participants who scored less than the mean score were considered as having poor awareness on presentation of obstetric fistula.

Data Collection Tools And Techniques

For data collection a structured face to face questionnaire English version was adapted after review of different literatures and modified depending on the local situation and the research objective. Initially it was developed in English and it was translated to Tigrigna by an individual who was native to Tigrigna language. And it was translated back to English language by another individual in order to maintain its consistency. The questionnaire contained questions on socio demographic characteristics, source of health related information, History of contraceptive use, obstetric history, questions on risk factors, presentation and prevention of obstetric fistula. Three diploma midwife and four BSc level health professionals were recruited and trained as data collectors and $2 \mathrm{BSc}$ level midwives were recruited\& trained as supervisors.

Eligible participants were approached and requested to consent voluntarily to participate into the study. Upon consenting, a study number with a code was assigned for identification. Inclusion into the study was done by using proportion from the selected kebeles and then randomly select until the required sample size was achieved using face to face structured questionnaire. We have selected 12 kebeles randomly from the two districts and then random sampling technique was used to recruit households. List of house hold contains reproductive age a woman was used as sampling frame that is available with health extensions workers in each kebeles. The first house hold was selected by lottery method. For those who were two or more eligible reproductive age women in one house hold lottery method was used to select one of them.

\section{Data quality assurance and control}

The data collection instrument was pretested for accuracy of responses, language transparency, correctness of data collection tools, estimate the time required and the necessary amendment was considered based on it prior to the actual data collection. It was carried out one week proceeding to the actual data collection period, in five percent of non-study participants that fulfill the inclusion criteria. In addition, the data collectors were trained for one day on the techniques of data collection. The training 
also included importance of disclosing the possible benefit and purpose of the study to the study participants before the start of data collection. Maintaining confidentiality of the participants throughout the whole process of data collection was discussed and ascertained during the training. The researcher was checked for completeness and consistency of questionnaires filled by the data collectors to ensure the quality of the data, and also visit the data collectors as many times as possible to check whether he/she collect the data appropriately. The researcher was also appraising the data during the data analysis stage to verify the completeness of the collected data.

Data Processing and Analysis

After data collection, Epi data version 4.2 was used for entry and then exported to SPSS version 20 for analysis. Binary logistic regression model was used to determine the factors associated with obstetric fistula. Those variables which were clinically important and having a $\mathrm{P}<0.25$ in bivariate analysis were the candidate variables for the final multi-variable binary logistic regression model. The crude and adjusted measures of effect odds ratio were determined with $95 \% \mathrm{Cl}$ and $\mathrm{P}<0.05$ was used to declare statistical significance. Goodness of fit of the final model was assessed using Hosmer and Lemeshow Goodness of fit test and multicolinearity was checked. Finally the result was presented using tables, figures, and texts.

\section{Results}

\section{Socio-demographic Character of the study participants}

In this study, 605 reproductive age women had interviewed and the response rate was $100 \%$. The mean age and standard deviation of the respondents were $30.7 \pm 9.313$ (range; $15-49$ years). Around, $24 \%$ of participants who had Good awareness on presentation for obstetric fistula were found in the age of 40-44 years. The result revealed that total of $(90 \%)$ participants who had good awareness regarding presentation of obstetric fistula were orthodox followers. Concerning marital status of respondents, around $103(54 \%)$ of participants who were found with good awareness on presentation of obstetric fistula were married. It was found that $66(35 \%)$ of reproductive age women found with good awareness on presentation of obstetric fistula were those with above secondary educational level. With regard to their occupation, $26 \%$ of respondents who had good awareness regarding presentation of obstetric fistula were those government employed (Table 1) 
Table 1

Socio-demographic characteristics of respondents among reproductive age women in south eastern zone of Tigray, Ethiopia 2020, ( $N=605)$.

\begin{tabular}{|c|c|c|c|}
\hline \multirow[t]{2}{*}{ Variable } & \multirow[t]{2}{*}{ Category } & \multicolumn{2}{|c|}{ Awareness on } \\
\hline & & Good & Poor \\
\hline \multirow[t]{7}{*}{ Age(years) } & $15-19$ & $29(15 \%)$ & $61(15 \%)$ \\
\hline & $20-24$ & $33(17 \%)$ & $71(16 \%)$ \\
\hline & $25-29$ & $33(17 \%)$ & $48(14 \%)$ \\
\hline & $30-34$ & $35(18 \%)$ & $60(15 \%)$ \\
\hline & $35-39$ & $12(6 \%)$ & $39(8 \%)$ \\
\hline & $40-44$ & $45(24 \%)$ & $104(24 \%)$ \\
\hline & $45-49$ & $4(3 \%)$ & $31(8 \%)$ \\
\hline \multirow[t]{2}{*}{ Religion } & Orthodox & 172(90\%) & $376(91 \%)$ \\
\hline & Muslim & $19(10 \%)$ & $38(9 \%)$ \\
\hline \multirow[t]{4}{*}{ Marital status } & Single & $61(32 \%)$ & $119(29 \%)$ \\
\hline & Married & $103(54 \%)$ & $264(63 \%)$ \\
\hline & Divorced & $20(11 \%)$ & $19(4 \%)$ \\
\hline & Widowed & $7(4 \%)$ & $12(3 \%)$ \\
\hline \multirow[t]{2}{*}{ Ethnicity } & Tegaru & $191(100 \%$ & 409(99\%) \\
\hline & Others & $1(0 \%)$ & $4(1 \%)$ \\
\hline \multirow{3}{*}{$\begin{array}{l}\text { age during } \\
\text { marriage }\end{array}$} & $<15$ & $24(19 \%)$ & $89(30 \%)$ \\
\hline & $15-19$ & $69(53 \%)$ & $163(55 \%)$ \\
\hline & $20-24$ & $37(28 \%)$ & $43(15 \%)$ \\
\hline \multirow[t]{4}{*}{ Educational level } & Not educated & $27(14 \%)$ & $259(63 \%)$ \\
\hline & Primary education & $42(22 \%)$ & $38(9 \%)$ \\
\hline & Secondary education & $56(29 \%)$ & $74(18 \%)$ \\
\hline & Above secondary & $66(35 \%)$ & $43(10 \%)$ \\
\hline Occupation & House wife & $25(13 \%)$ & $86(21 \%)$ \\
\hline
\end{tabular}

Note: Others* in ethnicity refers to Amhara and Afar 


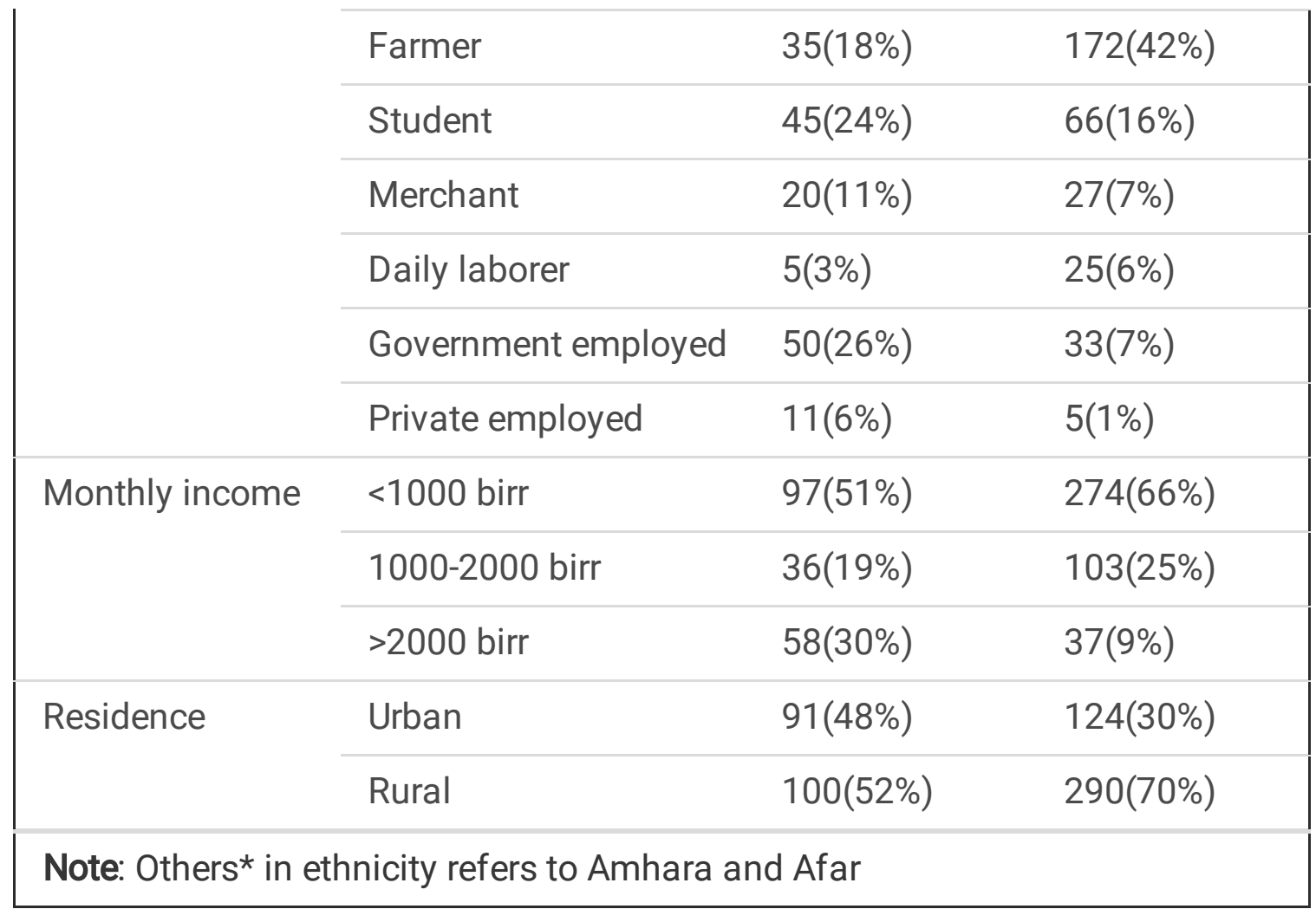

\section{Awareness On Presentation Of Obstetric Fistula}

Reproductive age women who had good awareness on presentation of obstetric fistula were 191(31.6\%). (Figure 1)

\section{Obstetric factors}

Three hundred eighty eight (64\%) respondents were heard about obstetric complication, and from the total $165(86 \%)$ respondents who had Good awareness regarding presentation of obstetric fistula were those participants who had ever heard about obstetric complication. About history of birth complication, $66(53 \%)$ of those who had good awareness on presentation of obstetric fistula were those with history of birth complication. from the total study participants, 319(52.7\%) of them used modern contraceptive, Of the total $135(71 \%)$ participants found with good awareness regarding presentation of obstetric fistula were those who had history of modern contraceptive use.Around $73.4 \%$ of reproductive age women had history of ANC, and $110(89 \%)$ of those found with good awareness on presentation of obstetric fistula were those who had history of ANC follow up. This study has shown that $(61.9 \%)$ of the respondents had history of institutional delivery, besides to that, $110(89 \%)$ of participants who had good awareness on presentation of obstetric fistula were found with those participant who had history of institutional delivery. (Table2) 
Table 2: Obstetric factors of respondents among reproductive age women in south eastern zone of Tigray, Ethiopia 2020

\begin{tabular}{|c|c|c|c|}
\hline \multirow[t]{2}{*}{ Variable } & \multirow[t]{2}{*}{ Category } & \multicolumn{2}{|c|}{ Awareness presentation of obstetric fistula } \\
\hline & & Good & Poor \\
\hline \multirow[t]{2}{*}{ Heard obstetric complication( $\mathrm{N}=605)$} & YES & $165(86 \%)$ & $223(54 \%)$ \\
\hline & NO & $26(14 \%)$ & $191(46 \%)$ \\
\hline \multirow[t]{2}{*}{ History of induced Abortion( $\mathrm{N}=391$} & YES & $54(44 \%)$ & $84(32 \%)$ \\
\hline & NO & $70(56 \%)$ & $183(68 \%)$ \\
\hline \multirow[t]{2}{*}{ History of birth complications $(\mathrm{N}=391$} & YES & $66(53 \%)$ & $116(43 \%)$ \\
\hline & NO & $58(47 \%)$ & $151(57 \%)$ \\
\hline \multirow{2}{*}{$\begin{array}{l}\text { Contraceptive history } \\
(\mathrm{N}=605)\end{array}$} & YES & $135(71 \%)$ & $184(44 \%)$ \\
\hline & NO & $56(29 \%)$ & $230(56 \%)$ \\
\hline \multirow{5}{*}{ Types of contraceptive use(320) } & Injection & $45(33 \%)$ & $85(46 \%)$ \\
\hline & Pill & $27(20 \%)$ & $43(23 \%)$ \\
\hline & Implant & $44(33 \%)$ & $51(28 \%)$ \\
\hline & IUCD & $7(5 \%)$ & $2(1 \%)$ \\
\hline & Condom & $12(9 \%)$ & $4(2 \%)$ \\
\hline \multirow[t]{2}{*}{ Ever been pregnant $(\mathrm{N}=605)$} & YES & $123(64 \%)$ & $266(64 \%)$ \\
\hline & NO & $68(36 \%)$ & $148(36 \%)$ \\
\hline \multirow{3}{*}{$\begin{array}{l}\text { Age during first pregnancy } \\
(\mathrm{N}=391)\end{array}$} & $15-19$ years & $49(40 \%)$ & $155(58 \%)$ \\
\hline & $20-24$ & $55(44 \%)$ & $99(37 \%)$ \\
\hline & $25-29$ & $20(16 \%)$ & $13(5 \%)$ \\
\hline \multirow{3}{*}{$\begin{array}{l}\text { № of pregnancy } \\
(\mathrm{N}=391)\end{array}$} & 1-3 times & $90(73 \%)$ & $134(50 \%)$ \\
\hline & 4-7 times & $24(19 \%)$ & $80(30 \%)$ \\
\hline & 8-11 times & $10(8 \%)$ & $53(20 \%)$ \\
\hline \multirow{2}{*}{$\begin{array}{l}\text { History of ANC for the index pregnancy } \\
(\mathrm{N}=391)\end{array}$} & YES & $110(89 \%)$ & $177(66 \%)$ \\
\hline & NO & $14(11 \%)$ & $90(34 \%)$ \\
\hline \multirow[t]{2}{*}{ Place of delivery(for the index child) } & Institution & $110(89 \%)$ & $132(49 \%)$ \\
\hline & Home & $14(11 \%)$ & $135(51 \%)$ \\
\hline
\end{tabular}




\section{Other factors for awareness on obstetric fistula}

Four hundred eighty nine (80.8\%) of the respondents were responsible in deciding to visit health facility by themselves. And $168(88 \%)$ of the study participants who had Good awareness on presentation of obstetric fistula. Out of the total respondents, $345(57 \%)$ head of the house were husbands, and around $95(49.7 \%)$ of respondents who had good awareness on, presentation of obstetric fistula were found to those husband head of house hold. All (100\%) of the participants had health facility in their kebele, and about distance to reach health facility, 211 (35\%) take them $<=30$ minute to visit health facility. About $81(42.4 \%)$ of respondents with good awareness on, presentation of obstetric fistula were those who traveled $<=30$ minutes to reach health facility (Table3)

Table 3: Other factors of respondents among reproductive age women in south eastern zone of Tigray, Ethiopia 2020 


\begin{tabular}{|c|c|c|c|}
\hline \multirow[t]{2}{*}{ Variable } & \multirow[t]{2}{*}{ Category } & \multicolumn{2}{|c|}{$\begin{array}{l}\text { Awareness on presentation of } \\
\text { obstetric fistula }\end{array}$} \\
\hline & & Good & Poor \\
\hline \multirow{4}{*}{$\begin{array}{l}\text { Who is responsible for you in deciding to visit } \\
\text { health facility? }\end{array}$} & Participant & 168(88\%) & $321(75.5 \%)$ \\
\hline & Husband & $13(6.8 \%)$ & 65(15.7\%) \\
\hline & Mother & $7(3.7 \%)$ & $19(4.6 \%)$ \\
\hline & Father & $3(1.6 \%)$ & $9(2.2 \%)$ \\
\hline \multirow{4}{*}{$\begin{array}{l}\text { Who is the head of household? } \\
(\mathrm{N}=605)\end{array}$} & Participant & $55(28.8 \%)$ & $95(22.9 \%)$ \\
\hline & Husband & $95(49.7 \%)$ & $250(60.4 \%)$ \\
\hline & Father & $31(16.2 \%)$ & $54(13 \%)$ \\
\hline & Mother & $10(5.2 \%)$ & $15(3.6 \%)$ \\
\hline \multirow{4}{*}{$\begin{array}{l}\text { House hold head education } \\
(\mathrm{N}=455)\end{array}$} & Not educated & $47(34.6 \%)$ & 154(48.3\%) \\
\hline & $\begin{array}{l}\text { Primary } \\
\text { education }\end{array}$ & $29(21.3 \%)$ & 101(31.7\%) \\
\hline & $\begin{array}{l}\text { Secondary } \\
\text { education }\end{array}$ & $28(20.6 \%)$ & 42(13.2\%) \\
\hline & $\begin{array}{l}\text { Above } \\
\text { secondary }\end{array}$ & $32(23.5 \%)$ & $22(6.9 \%)$ \\
\hline \multirow{7}{*}{$\begin{array}{l}\text { Distance to health facility }(605) \\
\text { source of health related information } \\
(\mathrm{N}=605)\end{array}$} & $<=30$ minute & $81(42.4 \%)$ & $130(31.4 \%)$ \\
\hline & $>30$ minute & $110(57.6 \%)$ & $284(68.6 \%)$ \\
\hline & Radio & $42(22 \%)$ & $160(38.6 \%)$ \\
\hline & Television & $26(13.6 \%)$ & $41(9.9 \%)$ \\
\hline & HEWs & $64(33.5 \%)$ & $123(29.7 \%)$ \\
\hline & Health facility & $51(26.7 \%)$ & $80(19.3 \%)$ \\
\hline & Others & $8(4.2 \%)$ & $10(2.4 \%)$ \\
\hline
\end{tabular}

\section{General awareness on obstetric fistula}

Reproductive age women who have ever heard about obstetric fistula were 368(60.8\%).And around $284(85 \%), 238(93 \%)$ and $170(89 \%)$ of study participants who had good awareness on prevention, risk factors and presentation for obstetric fistula respectively were those who had prior information about 
obstetric fistula. On source of information about obstetric fistula, 196 (53.3\%) was media and $129(54.2 \%), 96(56.5 \%)$ and $151(52 \%)$ of women with good awareness regarding risk factors, presentation and prevention for obstetric fistula were got information from media. (Table4)

Table 4

Awareness on obstetric fistula among reproductive age women in south eastern zone of Tigray, Ethiopia 2020

\begin{tabular}{|c|c|c|c|}
\hline \multirow[t]{2}{*}{ Variable } & \multirow[t]{2}{*}{ Category } & \multicolumn{2}{|c|}{$\begin{array}{l}\text { Awareness presentation o } \\
\text { Obstetric fistula }\end{array}$} \\
\hline & & Good & Poor \\
\hline \multirow[t]{2}{*}{ Have ever heard obstetric fistula? $(\mathrm{N}=605)$} & YES & $170(89 \%)$ & $198(48 \%)$ \\
\hline & NO & $21(11 \%)$ & $216(52 \%)$ \\
\hline \multirow{7}{*}{$\begin{array}{l}\text { Symptom of obstetric fistula u } \\
\text { heard }(\mathrm{N}=368)\end{array}$} & Urine incontinency & $110(65 \%)$ & $96(49 \%)$ \\
\hline & Fecal incontinency & $1(0.6 \%)$ & $4(2 \%)$ \\
\hline & $\begin{array}{l}\text { Urine and fecal } \\
\text { incontinency }\end{array}$ & $15(8.8 \%)$ & $16(8.1 \%)$ \\
\hline & $\begin{array}{l}\text { Foul smelling vaginal } \\
\text { liquid }\end{array}$ & $6(3.5 \%)$ & $9(4.3 \%)$ \\
\hline & $\begin{array}{l}\text { Urine incontinency and } \\
\text { smelling }\end{array}$ & $6(3.5 \%)$ & $10(5.1 \%)$ \\
\hline & $\begin{array}{l}\text { Urine, fecal incontinency } \\
\text { and smelling }\end{array}$ & $7(4.1 \%)$ & $3(1.5 \%)$ \\
\hline & I don't know & $25(14.5 \%)$ & $60(30 \%)$ \\
\hline \multirow{4}{*}{$\begin{array}{l}\text { From where you got information about } \\
\text { obstetric fistula? }(\mathrm{N}=368)\end{array}$} & Health facility & $59(34.7 \%)$ & $75(37.6 \%)$ \\
\hline & $\begin{array}{l}\text { Family, relative and } \\
\text { friends }\end{array}$ & $8(4.7 \%)$ & $17(8.4 \%)$ \\
\hline & Media & $96(56.5 \%)$ & $100(51 \%)$ \\
\hline & Victims of fistula & $7(4.1 \%)$ & $6(3 \%)$ \\
\hline
\end{tabular}

\section{Associated factors of Awareness on presentation of Obstetric Fistula}

Binary logistic regression was done to identify significant factors with the awareness on presentation of obstetric fistula then those factors with p-value of less than 0.25 during bivariate analysis had been taken to multivariable analysis. The variables significantly associated in bivariate analysis were, Educational 
level, place of delivery for index child ,Prior information About obstetric fistula, residence, distance to health facility, Frequency of pregnancy, History of birth complication and History of ANC(for the index pregnancy).The multivariable binary logistic regression analysis showed the following outcome: Educational level, place of delivery (for the index child),Prior information about obstetric fistula were independently associated with awareness on presentation of obstetric fistula, Reproductive age women who had above secondary educational level were 2.9 times more likely to have good awareness on presentation of obstetric fistula as compared to those reproductive age women who were not educated $[\mathrm{AOR}(95 \% \mathrm{Cl}=2.9(1.42-9.6)]$. women who had history of institutional delivery (for the index child) were 4.1 times more likely to have good awareness on presentation of obstetric fistula as compared to those who had had experience of home delivery[AOR $(95 \% \mathrm{Cl}=4.1(1.76-9.56)]$. Reproductive age women who had prior information about obstetric fistula were found to be 2.2 times more likely to have good awareness on presentation of obstetric fistula as compared to those who had not [AOR (95\% Cl=2.2(1.01-4.75)] . (Table5)

Table5: Associated factors of Awareness on presentation of Obstetric Fistula among reproductive age women in south eastern zone of Tigray, Ethiopia 2020. 


\begin{tabular}{|c|c|c|c|c|c|}
\hline \multirow[t]{2}{*}{ Variable } & \multirow[t]{2}{*}{ Category } & \multicolumn{2}{|c|}{$\begin{array}{l}\text { Awareness on presentation } \\
\text { of obstetric fistula }\end{array}$} & \multirow[t]{2}{*}{$\operatorname{coR}(95 \% \mathrm{Cl})$} & \multirow[t]{2}{*}{ AOR $(95 \% \mathrm{Cl})$} \\
\hline & & Good & Poor & & \\
\hline \multirow[t]{4}{*}{ Educational level } & Not educated & $27(14 \%)$ & $259(63 \%)$ & 1 & 1 \\
\hline & $\begin{array}{l}\text { Primary } \\
\text { education }\end{array}$ & $42(22 \%)$ & $38(9 \%)$ & $\begin{array}{l}1.6(.657- \\
2.244)\end{array}$ & $\begin{array}{l}0.61(0.28- \\
1.34)\end{array}$ \\
\hline & $\begin{array}{l}\text { Secondary } \\
\text { education }\end{array}$ & $56(29.4 \%)$ & 74(18\%) & $\begin{array}{l}7.3(4.152- \\
9.39)^{\star \star}\end{array}$ & $\begin{array}{l}1.23(.57- \\
2.94)\end{array}$ \\
\hline & $\begin{array}{l}\text { Above } \\
\text { secondary } \\
\text { Education }\end{array}$ & $66(34.6 \%)$ & $43(10 \%)$ & $\begin{array}{l}14.7(8.24- \\
17.25)^{\star \star}\end{array}$ & $\begin{array}{l}2.9(1.42- \\
9.6)^{\star \star}\end{array}$ \\
\hline \multirow[t]{2}{*}{$\begin{array}{l}\text { place of delivery (for } \\
\text { the index child) }\end{array}$} & Institution & $110(88.7 \%)$ & $132(49.4 \%)$ & $\begin{array}{l}8(4.38- \\
14.73)^{\star \star}\end{array}$ & $\begin{array}{l}4.1(1.76- \\
9.56) * *\end{array}$ \\
\hline & Home & 14(11.3\%) & 135(50.6\%) & 1 & 1 \\
\hline \multirow{2}{*}{$\begin{array}{l}\text { Prior information } \\
\text { About obstetric } \\
\text { fistula }\end{array}$} & YES & 170(89\%) & 198(47.8\%) & $\begin{array}{l}8.83(5.4- \\
14.5)^{\star \star}\end{array}$ & $\begin{array}{l}2.2(1.016- \\
4.75)^{*}\end{array}$ \\
\hline & NO & $21(11 \%)$ & $216(52.2 \%)$ & 1 & 1 \\
\hline \multirow[t]{2}{*}{ Residence } & Urban & $91(47.6 \%)$ & 124(30\%) & $\begin{array}{l}2.13(1.495- \\
3.03)^{\star \star}\end{array}$ & $\begin{array}{l}1.35(.682- \\
2.661)\end{array}$ \\
\hline & Rural & $100(52.4 \%)$ & $290(70 \%)$ & 1 & 1 \\
\hline \multirow[t]{2}{*}{$\begin{array}{l}\text { Distance to health } \\
\text { facility }\end{array}$} & $<=30$ minute & $81(42.4 \%)$ & 130(31.4\%) & $\begin{array}{l}1.61(1.13- \\
2.3)^{\star}\end{array}$ & $\begin{array}{l}1.48(.348- \\
1.316)\end{array}$ \\
\hline & $>30$ minute & $110(57.6 \%)$ & $284(68.6 \%)$ & 1 & 1 \\
\hline \multirow[t]{3}{*}{$\begin{array}{l}\text { Frequency of } \\
\text { pregnancy }\end{array}$} & 1-3 times & $90(72.6 \%)$ & $134(50.1 \%)$ & $\begin{array}{l}3.6(1.7- \\
7.4)^{*}\end{array}$ & $\begin{array}{l}0.8 .9(.474- \\
1.684)\end{array}$ \\
\hline & 4-7 times & $24(19.4 \%)$ & $80(30 \%)$ & $\begin{array}{l}1.6(.704- \\
3.593)\end{array}$ & $\begin{array}{l}1.051(.433- \\
2.553)\end{array}$ \\
\hline & 8-11 times & $10(8 \%)$ & $53(19.9 \%)$ & 1 & 1 \\
\hline \multirow[t]{2}{*}{$\begin{array}{l}\text { History of birth } \\
\text { complication }\end{array}$} & YES & $66(53.2 \%)$ & 116(43.4\%) & $\begin{array}{l}1.5(.966- \\
2.272)\end{array}$ & $\begin{array}{l}1.2(.716- \\
1.99)\end{array}$ \\
\hline & NO & $58(46.8 \%)$ & 151(56.6\%) & 1 & 1 \\
\hline \multirow[t]{2}{*}{$\begin{array}{l}\text { History of } \\
\text { ANC(index) }\end{array}$} & YES & $110(88.7 \%)$ & 177(66.3\%) & $4(2.2-7.4)^{\star \star}$ & $\begin{array}{l}1.14(.499- \\
2.611)\end{array}$ \\
\hline & NO & 14(11.3\%) & $90(33.7 \%)$ & 1 & 1 \\
\hline
\end{tabular}

Note: ${ }^{*}=$ significant at $p$-value $<0.05, * *=$ significant at $p<.001 \& 1=$ reference 


\section{Discussion}

Community based cross-sectional study was carried out to assess the awareness status on presentation of obstetric fistula and associated factors among reproductive age women living in south eastern zone of Tigray regional state.

The finding of this study indicated the awareness status of reproductive age women on presentation of obstetric fistula and the effect of reproductive age women's education, place of delivery for the index child and prior information about obstetric fistula on awareness on presentation of obstetric fistula.

About reproductive age women $31.6 \%(95 \% \mathrm{Cl}=28 \%-35 \%)$ had good awareness on presentation of obstetric fistula; this result was lower than the study conducted in Ghana(17) which was $45.8 \%$. But it was higher than a study conducted in Bangladesh(18) which was $12 \%$. This difference could be due to difference in study setting, because the study in Bangladesh was conducted in rural areas where there is poor access to share health related information due to shortage of infrastructure. But our study was carried out including reproductive age women living in urban where there is expected to have good infrastructure and media to share information about obstetric fistula.

Factors which affect awareness on presentation of obstetric fistula were identified. Reproductive age women with higher than secondary level of education had statistically significant association with awareness on presentation of obstetric fistula [AOR $(95 \% \mathrm{Cl}=2.9(1.42-9.6)$ ] as compared to women who were not educated. This finding was consistent with the study conducted in Ethiopia Oromia region(19).

Women who had history of institutional delivery had statically significant association on awareness on presentation of obstetric fistula [AOR $(95 \% \mathrm{Cl}=4.1(1.76-9.56)]$ as compared to those who had had experience of home delivery. This finding was also consistent with study conducted in Amhara region Ethiopia(20).

Moreover the odds of awareness were higher among those who prior heard about obstetric fistula by 2.2 times as compared to those who did not hear before [AOR $(95 \% \mathrm{Cl}=2.2(1.01-4.75)]$. This might be justified as; having prior information about something can shape one's awareness, so those who ever heard about obstetric fistula have better awareness.

\section{Conclusions}

Generally this study has disclosed that awareness on presentation for obstetric fistula among reproductive age women was poor. Level of education, place of delivery for the index child, and prior information about obstetric fistula were significant predictors for awareness of reproductive age women regarding presentation of obstetric fistula.

\section{Abbreviations}


ACSH-Ayder comprehensive Specialized Hospital, AOR-Adjusted odds ratio, COR-crude odds ratio, $\mathrm{Cl}$ Confidence interval, CS-Cesarean section, CSA-Central Statistical Agency,

EDHS-Ethiopia Demographic health survey, FGD-Focused Group Discussion,

NGOs -None Governmental Organizations, OF-Obstetric Fistula, SBAs-Skilled Birth Attendants

SPSS-Statistical package for social science, SSA-Sub-Saharan Africa, TBAs-Traditional Birth Attendants, VVF-Vesico- Vaginal Fistula, WHO-World Health Organization

\section{Declarations}

\section{Ethical consideration}

Before the actual data collection letter of permission was obtained from Mekelle University, health Science College and school of Nursing to Tigray health bureau and then to south eastern zone Districts health Bureaus, the objective of the study was explained to the study participants. Privacy and confidentiality of the study participants were maintained by using study codes on data documents without identifiers on the study instruments except serial numbers. Furthermore, the study participant involvement was based on their willingness.

\section{Consent for publication}

Not applicable

\section{Availability of data and materials}

The datasets used during the current study available from the corresponding author on reasonable request.

\section{Computing interest}

The authors declare that they have no competing interests.

\section{Funding}

Mekelle University was our fund agent to conduct this study. The role of Mekelle University was providing appropriate training to develop the proposal, funding money to our data collectors and following how the study is going on, finally, our University provides us basic training which was helpful for our study.

\section{Authors' contributions}

All authors performed statistical analysis, and drafted the paper, in paper writing, the data analysis and read and approved the final paper. 


\section{Acknowledgments}

We are highly indebted to all participants of the study, supervisors of data collection and data collectors for their worthy efforts and participation in this study. We are also thankful for administrative bodies at all levels who endorsed us to undertake these studies.

\section{References}

1. Tunçalp Ö, Tripathi V, Landry E, Stanton CK, Ahmed S. Measuring the incidence and prevalence of obstetric fistula: Approaches, needs and recommendations. Bull World Health Organ. 2015;93(1):602.

2. Mselle LT, Kohi TW. Perceived Health System Causes of Obstetric Fistula from Accounts of Affected Women in Rural Tanzania: A qualitative study. Afr J Reprod Health. 2015;19(March):124-32.

3. Tebeu PM. Risk factors for obstetric fistula: a clinical review. int Urogynecol J 2012. 2012;23(4):38794.

4. Adler AJ, Ronsmans C, Calvert C, Filippi V. Estimating the prevalence of obstetric fistula: A systematic review and meta-analysis. BMC Pregnancy Childbirth [Internet]. 2013;13(1):1-14. Available from: BMC Pregnancy and Childbirth.

5. Dangal G, Thapa K, Yangzom K, Karki A. Obstetric Fistula in the Developing World: An Agonising Tragedy Obstetric Fistula in the Developing World : An Agonising Tragedy. Nepal J Obstet Gynaecol. 2014;(February).

6. Tebeu PM, Fomulu JN, Khaddaj S, Bernis L, De, Delvaux T, Rochat CH. Risk factors for obstetric fistula: a clinical review. Int Urogynecol J. 2012;387-94.

7. WHO. International Day to End Obstetric Fistula. Who [Internet]. 2013;100000. Available from: https://www.who.int/pmnch/media/events/2013/fistuladay/en/.

8. Lim SS, Allen K, Dandona L, Forouzanfar MH, Fullman N, Goldberg EM, et al. Measuring the healthrelated Sustainable Development Goals in 188 countries: a baseline analysis from the Global Burden of Disease Study 2015. Lancet. 2016;388(10053):1813-50.

9. Ezeonu PO, Ekwedigwe KC, Isikhuemen ME, Eliboh MO, Onoh RC, Lawani LO, et al. Awareness of Obstetric Vesicovaginal Fistula among Pregnant Women in a Rural Hospital. Adv Reprod Sci. 2017;05(03):39-46.

10. Ezeonu PO, Ekwedigwe KC, Isikhuemen ME, Eliboh MO, Onoh RC, Lawani LO, et al. Awareness of Obstetric Vesicovaginal Fistula among Pregnant Women in a Rural Hospital. Adv Reprod Sci. 2017; (August).

11. Reinhardt W, Mletzko C, Sloep PB. Understanding the Meaning of Awareness in Research Networks Understanding the meaning of awareness in Research Networks. Conf Pap · 2012;(July 2015).

12. Bellows B. Barriers to Obstetric Fistula Treatment. Popul Counc. 2017. 
13. Zheng AX, Harrington AH, Love SA, Thélémaque LD, Anderson FWJ. Fistula awareness among sisters of women with fistula International Journal of Gynecology and Obstetrics Fistula awareness among sisters of women with fi stula. Int J Gynecol Obstet [Internet]. 2018;120(3):232-5. Available from: http://dx.doi.org/10.1016/j.ijgo.2012.09.019.

14. Kabayambi J, Barageine JK, Matovu JKB. Living with Obstetric Fistula: Perceived Causes, Challenges and Coping Living with Obstetric Fistula : Perceived Causes, Challenges and Coping Strategies among Women Attending the Fistula Clinic at Mulago Hospital, Uganda. Natl J Trop Dis Heal. 2014; (June).

15. Pope R. Research in Obstetric Fistula Addressing Gaps and Unmet Needs Access to Repair. Obstet Gynecol. 2018;0(0):1-8.

16. Commission federal democratic repuplic of ethiopia population censucs. 4 Summary and Statistical Report of the 2007 Population and Housing Census Results. Popul size by age sex. 2007.

17. Jarvis K, Richter S, Vallianatos H, Thornton L. Reintegration of Women Post Obstetric Fistula Repair: Experience of Family Caregivers. Glob Qual Nurs Res. 2017.

18. Saha S, Ambauen-Berger B, Munira S. Baseline knowledge of female genital fistula symptoms, causes and treatment among a rural population in Northern Bangladesh. Nepal J Obstet Gynaecol. 2018;13(2):2-5.

19. Defar S. Awareness on obstetric fistula and its associated factors among reproductive women in Assela town. Dr dissertion,Addis Ababa Univ. 2018;(June).

20. yenealem F, Feyisa W, Nigusie ATA. Awareness and its associated factors of obstetrics fistula among pregnant mothers attending antenatal care clinics. Matern fetal Med. 2019;21203.

\section{Figures}

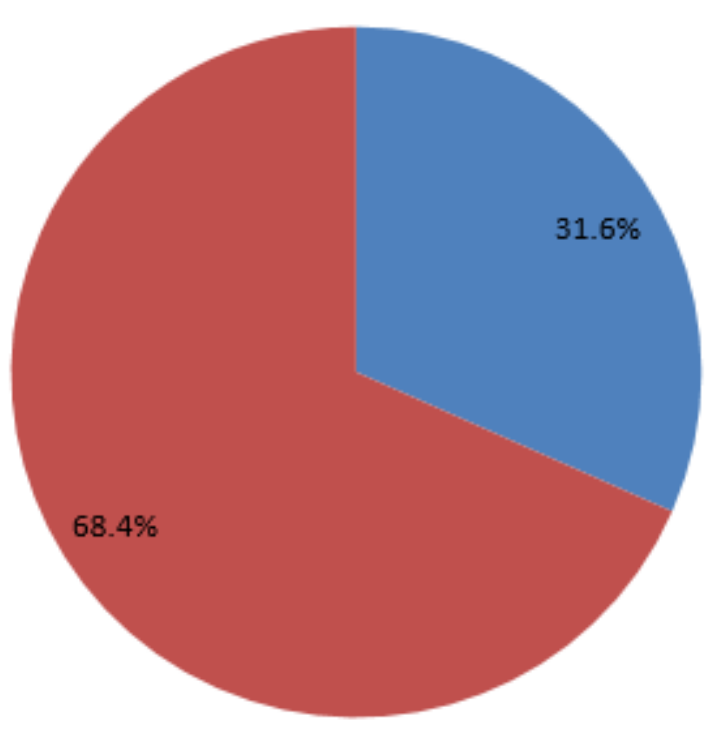

Good

- Poor 


\section{Figure 1}

the status of reproductive age women's Awareness on presentation of obstetric fistula in south eastern zone of Tigray, Ethiopia 2020, (N=605).

\section{Supplementary Files}

This is a list of supplementary files associated with this preprint. Click to download.

- BMCCL.Presen.docx 